Article

\title{
Species Assemblage and Biogeography of Japanese Protura (Hexapoda) in Forest Soils
}

\author{
Nobuhiro Kaneko ${ }^{1, *}$, Yukio Minamiya ${ }^{1}$, Osami Nakamura ${ }^{2}$, Masayuki Saito ${ }^{3}$ and \\ Minori Hashimoto ${ }^{4}$
}

1 Soil Ecology Research Group, Yokohama National University, Tokiwadai 79-7, Hodogaya, Yokohama 248-8501, Japan; E-Mail: minamiya.yukio@pref.saitama.lg.jp

2 Saitama Museum of Natural History, Nagatoro, Saitama 369-1305, Japan;

E-Mail: osami@nakamura.email.ne.jp

3 Graduate School of Arts and Sciences, The University of Tokyo, Komaba 3-8-1, Meguro 153-8902, Japan; E-Mail: saito.ume@gmail.com

4 Department of Socio-Human Environmentology, Daito Bunka University, Iwadoono 560, Higashimatsuyama 355-8501, Japan; E-Mail: mhashimoto@ic.daito.ac.jp

* Author to whom correspondence should be addressed; E-Mail: kanekono@ynu.ac.jp; Tel.: +82-45-339-4358; Fax: +82-45-339-4379.

Received: 10 June 2012; in revised form: 13 August 2012 / Accepted: 16 August 2012 / Published: 31 August 2012

\begin{abstract}
The distribution and species assembly of Japanese Protura collected from forest soils were examined using published databases and statistical analysis. We used records from 3110 sites where 71 taxa were found. The species richness of Protura ranged from one to 16 species, and TWINSPAN analysis of regional populations indicated that the northern and southern regions could be separated into distinct groups. Three major species assemblages were identified by cluster analysis from points containing more than six species. Three groups reflected historical migration from northern and western linkages to the Asian continent. The northern assemblage showed a negative correlation to winter minimum temperature and the other two assemblages exhibited relationships to precipitation and temperature. Vegetation was not responsible for proturan distribution. These results suggest that the history of Protura invasion explains the biogeography of these soil-based, small arthropods and also that climate change will induce a shift in the distribution of species irrespective of changes in vegetation type.
\end{abstract}


Keywords: biodiversity; geological history; GLM: soil arthropod; vegetation

\section{Introduction}

Human activities are expanding rapidly and are now exceeding planetary limitations for some indices, hence we should recognize the modern Anthropocene period as a time when human activity is highly influential on Earth systems [1]. Human disturbance of Earth systems includes climate change, pollution by chemicals and environmental eutrophication, and all of these changes can influence the global abundance and distribution of organisms. Soil organisms are important components of terrestrial ecosystems, and their activities are also linked to above-ground subsystems. Climate change may affect the activities of both above- and below-ground organisms, and because migration due to habitat change will be more rapid among above-ground species than below-ground species, climate change may induce a mismatch of response of the above- and below-ground members of a community [2].

The biogeography of soil organisms is still poorly understood. Fierer [3] reviewed the global biomass distribution of some soil organism groups. Microbial biomass was positively correlated with soil $\mathrm{pH}$ and carbon content, and there was also a positive relationship between the biomass of soil fauna and microbial biomass. Earthworms were less abundant in boreal systems and more biomass was observed in tropical forests and temperate grassland. Latitudinal gradients of species richness for native and invasive soil animals in North America have been studied [4], with results indicating that native species richness was higher in lower latitudes and decreased along a latitudinal gradient to the north. The biogeographical distribution of small organisms is often unclear because most microorganisms are hyper-abundant and possess a resting stage that enables them to disperse over a wide range. The range of $1-10 \mathrm{~mm}$ in body size is proposed as a transition region below which there is a lack of biogeographical knowledge of microbial species distribution [5].

The Protura are a microarthropod order that inhabit leaf litter and soil layers throughout their life cycle. The adult body size range is $0.5-2.5 \mathrm{~mm}$. All proturans lack eyes, wings and antennae; therefore, the dispersal ability is assumed to be very low. Mycorrhizal fungi are believed to be the main food source for Protura. Because it is possible to grow Protura in laboratory conditions using non-mycorrhizal fungi, proturan feeding is clearly not limited to mycorrhiza. The global number of known species is approximately 700 [6]. Two taxonomists; G. Imadaté and O. Nakamura, have intensively studied the Japanese proturan fauna, and have recorded 88 species in Japan. The postembryonic development of Protura is: egg-prelarva-larva I-larva II-maturus junior-preimago-imago. It is possible to identify species at all developmental stages, except for the prelarva stage. Because the density of Protura in soil is low compared to other soil arthropods, such as Collembola and mites, and they have low dispersal ability, the biogeography of Protura is likely to reflect the species invasion history and environmental heterogeneity. Recently, proturan fauna in east Asia were well investigated [7-15]; therefore, it will become possible to better understand the source of the Japanese fauna.

The aim of this study was to summarize the distribution of Protura in Japan and to clarify the determining environmental factors. The records obtained were from samples collected mainly in the 
1970's to 1990's, and represent a snapshot of soil fauna and their environment at that time. This can be referred back to as a baseline for management of biodiversity and environmental conservation.

\section{Methods}

\subsection{Study Area}

The Japanese Archipelago ranges ca. $3000 \mathrm{~km}$ from northern Hokkaido (4530' N) to Okinoshima Island $\left(20^{\circ} 25^{\prime} \mathrm{N}\right)$, with a mild climate and substantial precipitation. The climate range is very wide due to the long latitudinal expansion and high elevation mountain systems on the main islands; therefore, the climate is subarctic in the northern regions and higher mountains, tropical in some southern islands and subtropical in the south-west islands, southern Kyushu and Shikoku. Most of Japan experiences a temperate climate. Annual average temperature and precipitation ranges from $9{ }^{\circ} \mathrm{C}$ to $22{ }^{\circ} \mathrm{C}$, and 1000 to $4500 \mathrm{~mm}$, respectively. Subtropical forests occur in the south-west islands, temperate evergreen forests occur in the western part of Japan and deciduous broad-leaved and evergreen conifer forests are present in the north-east part of Japan. Forests are present in all regions of Japan and there is very little natural grassland.

\subsection{Data Sets}

We collected presence or absence data from published taxonomic papers and collection records that contained clear information regarding the collection sites and its vegetation and altitude [11-13,16-59]. These databases covered a wide range of Japanese regions, and the accuracy of species identification appeared to be consistent and reliable because only two taxonomists (Imadaté and Nakamura) performed the identification. However, sampling efforts and methods were not uniform because the field samples were obtained by various researchers.

We treated the records of Nipponentomon uenoi Imadaté et Yosii, 1959, as follows: Imadaté (1988) [18] classified six morphological types. Although there was no taxonomic status recorded for these six types, their geographical distribution showed complementarity; therefore, we treated all six types as independent taxa.

Some records were discarded due to uncertainty in identification; for example Eosentomon udagawai Imadaté, 1961 according to Nakamura [31] is composed of a species complex of E. asahi Imadaté, 1961 at Okinawajima Island. and E. pacificum Imadaté et Yosii, 1959 at Miyanoura, Kagoshima. We used data obtained in forests, alpine regions, coastal regions and grassland, whereas urban environments were not used. The WGS84 system was used to describe geographical position. The Free Address Geocoding Service for CSV formatted files on the WWW [60] was used to obtain geocodes for soil sampling locations.

\subsection{Regional Comparison of Species Composition}

We divided the area into 10 regions. Except Tsushima and Ryukyu, the area corresponding to municipal regions, there are no biogeographical regions studies for soil fauna in Japan, and the area used showed rather similar size (ranging from 116 to $598 \mathrm{~km}^{2}$ ), therefore we used this division for calculating similarity and richness of species. The Tsushima and Ryukyu Islands are small and had 
local species compositions in common with the Korean Peninsula and China/Taiwan, respectively; therefore, we treated them as independent regions. Sampling localities per unit area were calculated to compare the sampling effort. Estimated species richness was obtained by Chaol in EstimateS Version 8.2.0.

Species richness per sample was used to determine diversity hotspots by spatial analysis using the inverse distance weighted (IDW) method in ArcGIS 9.3. The output cell size was 0.005, the multiplier value was 3 , the search range was variable and the diameter of search was set to 50 .

Presence or absence was used to compare the similarity of species composition between regions. Species composition was classified using the TWINSPAN [61] method in PC-ORD [62], and the Jaccard index modified by Chao [57] was calculated between regions to determine the similarity in species composition of regions.

\subsection{Species Assemblages}

We selected sampling localities from which more than six species were obtained. These points were considered likely to represent stable environments without major human disturbance; therefore, these data reflect the long-term proturan history and adaptation to the environment. Cluster analysis was conducted using R version 2.13.0 packages [63]; vegan, ade4, gclus, cluster, RcolorBrewer, labdsv.

Indicator species for classified species assemblages were obtained by calculating IndVal [64] according to the method of Borcard et al. [65]. Logistic regression analysis was conducted using explanatory variables of vegetation, altitude, maximum and minimum temperature, annual precipitation, and the response variable of the presence of each assemblage. Broadleaved forest and conifer forest were assigned the values of 1 and 0 , respectively. Climate data were obtained from Mesh Climatic Data of Japan (2000) [66] during the period 1970 to 2000. This procedure provided long-term average climate conditions. The selection of the response variable included not only the best fitting model but also variables with less than 2 delta AIC.

\section{Results}

\subsection{Data Sets}

We selected the collection and identification records for 3110 sites (mostly forests) (Figure 1) in which 71 taxa (64 species, 3 subspecies and 4 formas) were recorded (Appendix: Table A1). A hot spot of species density was found in the central part of Japan (Chubu, Kanto and Tohoku) (Figure 1).

\subsection{Regional Species Composition}

The number of samples per unit area was highly biased. The islands of Tsushima and Ryukyu have been surveyed intensively (sample/area $\left(\mathrm{N} / 100 \mathrm{~km}^{2}\right)=4.9$ and 2.8), whereas less intensive records were obtained for Hokkaido, Tohoku, Chubu, Chugoku, Shikoku and Kyushu. Species richness in each region ranged from nine to 45 (Table 1), and was high in the central part of Honshu Island. (Kanto and Chubu). The difference between the actual and expected (Chao1) number of species [57] in each region was large in Kinki and Shikoku. However, the species richness was also high in Kanto and Chubu. 
Figure 1. (a) Sections of the Protura record reported by Imadate (red), Nakamura (blue), and others (green); (b) Species density distribution was estimated using the inverse distance weighted (IDW) interpolation method of ArcGIS; (c) Species distribution in the northern part of Honshu (Main Island composed of Tohoku, Kanto, Chubu, Kinki, and Chugoku) (enlarged). Color indicates estimated species richness in each locality in (panels b,c).

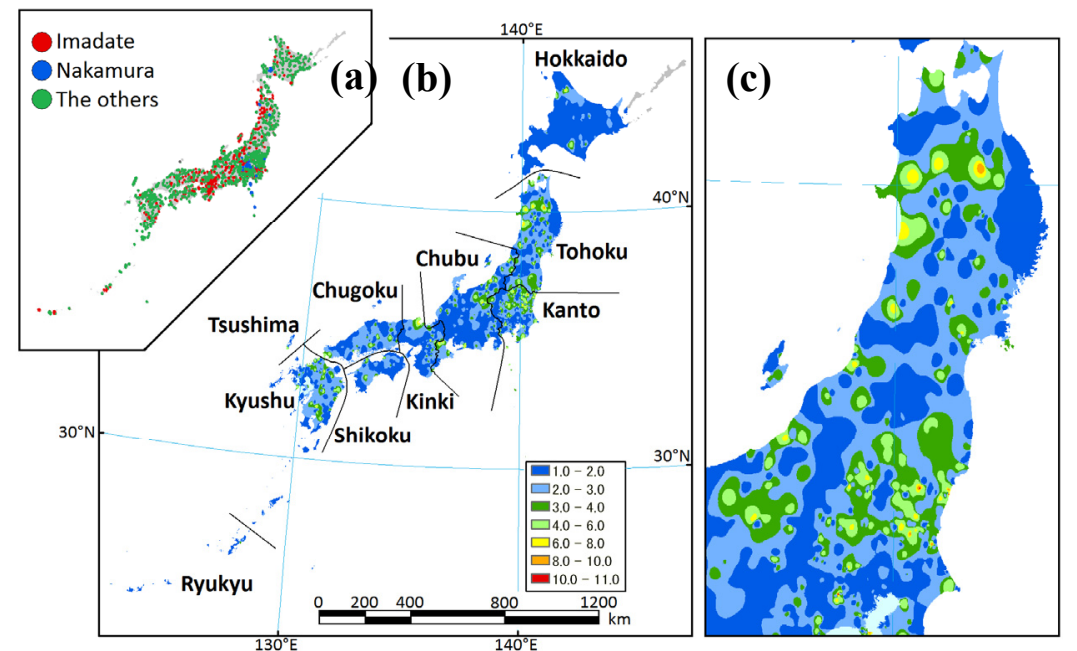

Table 1. The number of sampling localities and species richness.

\begin{tabular}{ccccccccccccc}
\hline Region & \multicolumn{1}{c}{ Hokkaido Tohoku Kanto Chubu Kinki Chugoku Shikoku Kyushu Tsushima Ryukyu Total } \\
\hline Numbers of sampling localities & 480 & 339 & 743 & 568 & 299 & 171 & 116 & 296 & 34 & 64 & 3110 \\
Area $\left(100 \mathrm{~km}^{2}\right.$ ) & 846 & 669 & 324 & 726 & 273 & 319 & 183 & 422 & 7 & 23 & 3792 \\
Ratio (N/Area $100 \mathrm{~km}^{2}$ ) & 0.6 & 0.5 & 2.3 & 0.8 & 1.1 & 0.5 & 0.6 & 0.7 & 4.9 & 2.8 \\
Total number of species & 27 & 30 & 43 & 45 & 22 & 17 & 20 & 20 & 12 & 9 & 71 \\
No. of expected species by Chao1 & 27.0 & 32.0 & 46.0 & 47.3 & 32.0 & 17.0 & 27.5 & 20.5 & 12.5 & 9.0 \\
\hline
\end{tabular}

The number of species per sampling point was highly skewed, with the species richness of Protura at each point ranging from 1 to 13 . More than $95 \%$ of the points contained fewer than five species (Figure 2).

Figure 2. Frequency distribution of the number of species obtained from each sampling point.

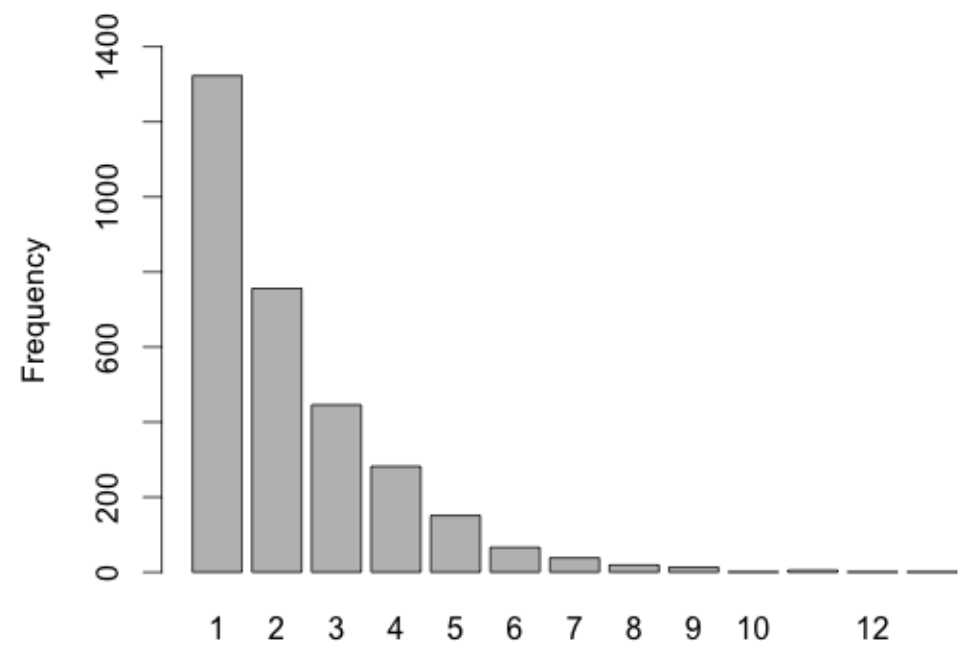


The first group obtained by the TWINSPAN procedure included Hokkaido, Tohoku and Kanto, in the northern part of Japan, where Hinomotentomon nipponicum (Imadaté, 1964) was commonly distributed. The second group contained Acerentulus keikoae keikoae Imadaté, 1988 in Chubu. The third was composed of A. k. capillatus Imadaté, 1988 in Kinki. The fourth separated the Ryukyu Islands, where Baculentulus densus (Imadaté, 1960) was not found. The remainders were Chugoku, Shikoku, Kyushu and Tsushima (Figure 3). B. morikawai (Imadaté et Yosii, 1956) and B. tosanus (Imadaté et Yosii, 1959), Eosentomon sakura Imadaté et Yosii, 1959 and Kenyentulus japonicus (Imadaté, 1961) were recorded in locations across Japan. The Jaccard similarity index between the localities showed a maximum between Kanto and Chubu (1.00, and a minimum between Hokkaido and Ryukyu (0.16) (Table 2).

Table 2. Species composition similarity (Modified Jaccard index [67]) matrix between the regional localities.

\begin{tabular}{cccccccccc}
\hline Region & Hokkaido & Tohoku & Kanto & Chubu & Kinki & Chugoku & Shikoku & Kyushu & Tsushima \\
\hline Tohoku & 0.82 & & & & & & & & \\
Kanto & 0.60 & 0.89 & & & & & & & \\
Chubu & 0.58 & 0.88 & 1.00 & & & & & & \\
Kinki & 0.49 & 0.61 & 0.74 & 0.93 & & & & & \\
Chugoku & 0.51 & 0.56 & 0.69 & 0.76 & 0.85 & & & & \\
Shikoku & 0.45 & 0.53 & 0.67 & 0.81 & 0.98 & 0.96 & & & \\
Kyushu & 0.44 & 0.49 & 0.62 & 0.71 & 0.95 & 0.95 & 0.96 & & \\
Tsushima & 0.36 & 0.37 & 0.51 & 0.57 & 0.70 & 0.81 & 0.81 & 0.83 & \\
Ryukyu & 0.16 & 0.31 & 0.43 & 0.51 & 0.59 & 0.58 & 0.55 & 0.57 & 0.43 \\
\hline
\end{tabular}

\subsection{Species Assembly}

Sampling localities containing more than six species were found at 144 localities, and all showed a skewed distribution (Table 3). There were no sampling localities with more than six species in Shikoku and Ryukyu.

Table 3. Data set used for species assembly analysis of Protura.

\begin{tabular}{cccccccccccc}
\hline Region & \multicolumn{1}{c}{ Hokkaido Tohoku Kanto Chubu Kinki Chugoku Shikoku Kyushu Tsushima Ryukyu } \\
\hline Numbers of sampling localities & 3 & 18 & 78 & 20 & 5 & 6 & 0 & 10 & 3 & 0 \\
\hline Area $\left(1000 \mathrm{~km}^{2}\right)$ & 8.5 & 6.7 & 3.2 & 7.3 & 2.7 & 3.2 & 1.8 & 4.2 & 0.1 & 0.2 \\
\hline Ratio (N/Area) & 0.4 & 2.7 & 24.1 & 2.8 & 1.8 & 1.9 & 0.0 & 2.4 & 42.9 & 0.0 \\
\hline
\end{tabular}

The localities classified into three clusters, following the species assembly by cluster analysis, are presented in Figure 4. Group-I contained points in the Hokkaido, Tohoku and Kanto regions and Group-II consisted of points in Tohoku, Kanto Chubu, Kinki and Chugoku. Group-III ranged widely from southern Tohoku to the west of Japan. The three groups overlapped in the Kanto area.

A GLM model of environmental selection for the three assembly groups selected mostly climatic factors (Table 4). Group-I showed a positive distribution toward less precipitation and lower minimum and maximum temperatures. Group-II showed a negative distribution toward precipitation, and 
Group-III had a positive distribution toward higher maximum and minimum temperatures and high precipitation. Vegetation type and altitude were not selected as important factors.

Figure 3. Regional species assembly (produced by TWINSPAN) of Protura. Numbers and species names on the dendrogram represent the eigenvalue and the indicator species.

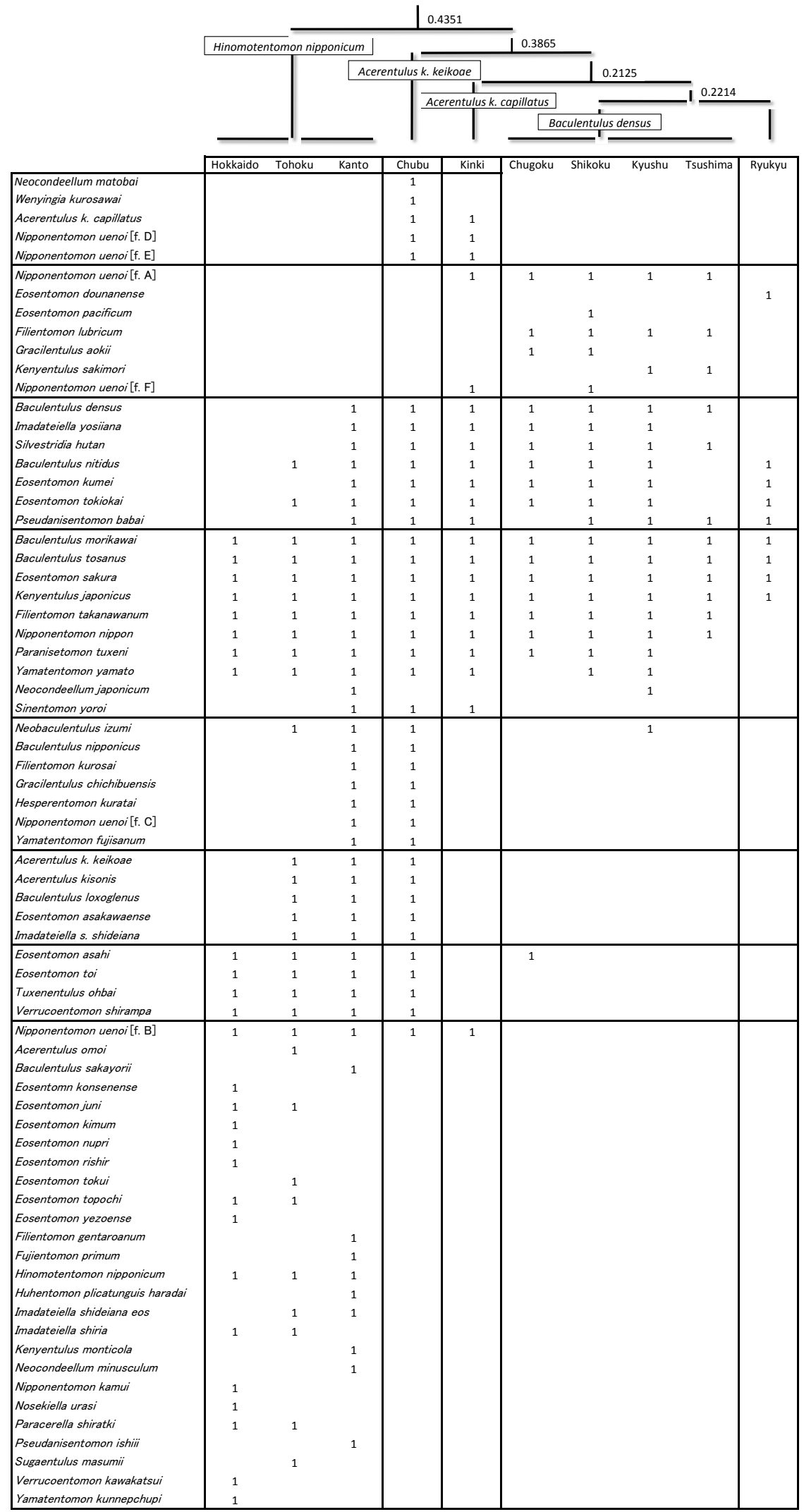


Figure 4. Cluster analysis and distribution of three Protura species assembly groups in which more than six species were recorded. IndVal analysis selected 7 to 9 indicator species from the three groups (Appendix: Table A2).

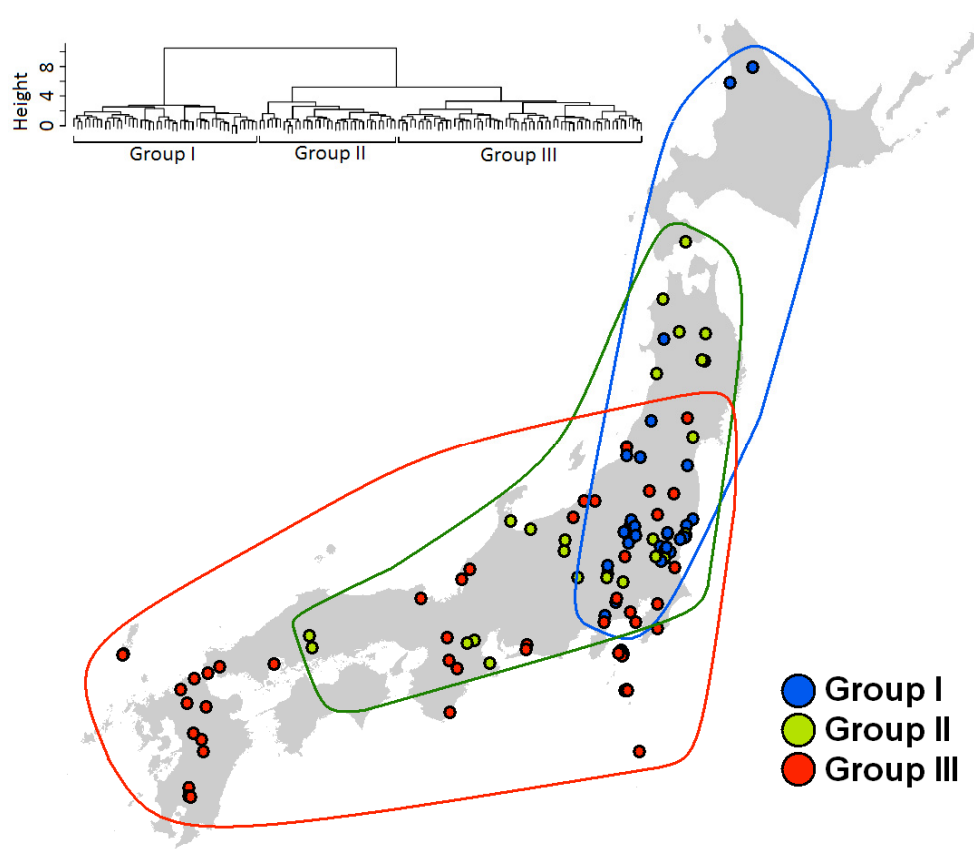

Table 4. GLM fit to the environmental variables of the three assembly groups of Protura.

\begin{tabular}{|c|c|c|c|c|c|c|c|c|c|c|}
\hline \multirow{2}{*}{ Group } & \multirow{2}{*}{$\begin{array}{c}\text { No. of } \\
\text { localities }\end{array}$} & \multirow{2}{*}{ Model } & \multirow{2}{*}{ Constant } & \multicolumn{5}{|c|}{ Standardized Regression Coefficient } & \multirow{2}{*}{ AIC } & \multirow{2}{*}{$\triangle \mathrm{AIC}$} \\
\hline & & & & Vegetation & Elevation & Max. Temp & Min. Temp & Precipitation & & \\
\hline \multirow{8}{*}{ Gr1 } & \multirow{8}{*}{47} & 1 & -0.87 & & & -0.81 & -0.59 & -0.49 & 153.05 & 0.00 \\
\hline & & 2 & -0.86 & & & -1.08 & & -0.77 & 153.85 & 0.80 \\
\hline & & 3 & -0.83 & & & -0.55 & -0.93 & & 154.49 & 1.44 \\
\hline & & 4 & -0.86 & -0.15 & & -0.85 & -0.53 & -0.53 & 154.53 & 1.48 \\
\hline & & 5 & -0.86 & -0.23 & & -1.09 & & -0.78 & 154.62 & 1.56 \\
\hline & & 6 & -0.87 & & -0.13 & -0.83 & -0.67 & -0.48 & 154.82 & 1.76 \\
\hline & & full & -0.86 & -0.14 & -0.10 & -0.86 & -0.60 & -0.52 & 156.39 & 3.34 \\
\hline & & null & -0.72 & & & & & & 183.9 & 30.85 \\
\hline \multirow{4}{*}{ Gr2 } & \multirow{4}{*}{35} & 1 & -1.60 & & & & & -1.49 & 137.78 & 0.00 \\
\hline & & 2 & -1.60 & & & 0.19 & & -1.45 & 138.97 & 1.19 \\
\hline & & 3 & -1.61 & & & 0.50 & -0.56 & -1.12 & 139.10 & 1.32 \\
\hline & & 4 & -1.60 & & 0.14 & & & -1.46 & 139.32 & 1.55 \\
\hline \multirow{5}{*}{ Gr2 } & \multirow{5}{*}{35} & 5 & -1.60 & 0.12 & & & & -1.48 & 139.44 & 1.66 \\
\hline & & 6 & -1.58 & & 0.27 & 0.30 & & -1.36 & 139.64 & 1.87 \\
\hline & & 7 & -1.60 & & & & -0.07 & -1.46 & 139.71 & 1.93 \\
\hline & & full & -1.60 & 0.16 & 0.17 & 0.55 & -0.54 & -1.07 & 141.94 & 4.16 \\
\hline & & null & -1.14 & & & & & & 161.72 & 23.94 \\
\hline \multirow{5}{*}{ Gr3 } & \multirow{5}{*}{62} & 1 & -0.50 & & & 0.75 & 1.83 & 1.13 & 120.56 & 0.00 \\
\hline & & 2 & -0.50 & & -0.12 & 0.72 & 1.76 & 1.13 & 122.45 & 1.90 \\
\hline & & 3 & -0.50 & 0.07 & & 0.77 & 1.82 & 1.14 & 122.47 & 1.91 \\
\hline & & full & -0.51 & 0.08 & -0.14 & 0.75 & 1.73 & 1.15 & 124.34 & 3.79 \\
\hline & & null & -0.28 & & & & & & 198.84 & 78.28 \\
\hline
\end{tabular}




\section{Discussion}

The biogeographical pattern shown in this study can be explained by the history of Protura invasions in Japan. Imadaté and Ohnishi (1993) [68] hypothesized that there were initially two groups of proturans established in Japan, each having a different origin. One group originated from Eastern Siberia through Sakhalin to Hokkaido, or through the Korean Peninsula to Northern Kyushu. Nipponentomon, Paracerella, Eosentomon tokui, Hesperentomon, and Wenyingia are the members of this group. In contrast, a second proturan group is thought to have a southern origin and flourishes in tropical Asia. Certain members have invaded from south and east China to Kyushu, including Baculentulus, Eosentomon sakura and its relatives, E. kumei, E. tokiokai, Fujientomon, and Sinentomon. The distribution of the three groups of the species assemblages found in this study reflected this hypothesis. The indicator species of Group I were found in Hokkaido and Tohoku, with the exception of Eosentomon asahi and Nipponentomon uenoi paucisetosum f. B., which have a wider distribution range. In contrast, all the indicator species of Group III were found in Kyushu, whereas more than half of these species extended their distribution to Hokkaido or Tohoku. Half of the Group II species showed a wide distribution range; however, others were found in a restricted area in the central part of Japan. E. sakura, B. tosanus, Paranisentomon tuxeni were considered to have a southern origin, whereas N. uenoi paucisetosum f. C and f. D, Filientomon takanawanum, Acerentulus, Yamatentomon yamato were of a northern origin. These three groups had an overlapping distribution in southern Tohoku, Kanto and Chubu, and actual and Chao 1 species richness were highest in these regions. TWINSPAN analysis supported the hypothesis that there are northern (Hokkaido, Tohoku) and other origin groups that have become separated. The other group was subdivided further, but it was obvious that regional similarity was higher in neighboring regions.

The present distribution of species assemblage was determined by climate (temperature and precipitation) but not by forest type or altitude. Although Lilleskov et al. [4] did not evaluate climate effects on the species richness of North American soil fauna, they found latitudinal richness gradients for most of the native soil fauna, therefore concluding that temperature can be an important factor acting on soil animals. We compared broadleaved forests and conifer forests, in which mycorrhizal species composition differed, but Protura did not show a clear response to the difference in vegetation type. Therefore, the link between Protura and mycorrhizal fungal species may not be strong.

The linkage history of the Japanese Archipelago to the Asian continent has been determined by geologists. The Japanese Archipelago was part of the continent before $22 \mathrm{Ma}$, and the archipelago was formed around $14 \mathrm{Ma}$ [69]. After several uplifts, downlifts and climatic oscillations, Ryukyu and Kyushu were separated by the deep Tokara Straight around $1 \mathrm{Ma}$, and Hokkaido and Tohoku were separated by the Tsugaru Straight around 0.15 Ma [70,71]. During the Pleistocene, Kyushu was connected several times to China and the Korean Peninsula, and Hokkaido was connected several times to Sakhalin until around 10,000 years ago. Therefore, both northern and southern routes to Japan were available $1 \mathrm{Ma}$, and movement of Protura was possible from Hokkaido to Kyushu for almost one million years.

The database used in this study was not uniformly collected, and the intensity of the survey per unit area was biased. Our analysis showed that species richness hotspots were located in Tohoku and Kanto, where the sampling effort contrasted. Therefore, we consider that the collection of Protura in this study 
is suitable for biogeographical analysis. Chao1 species richness was far higher than actual richness in Kinki and Shikoku. Therefore, further sampling efforts are required in these regions.

\section{Conclusions}

Most soil animals are hyper-diverse and are restricted to the soil habitat, while lacking significant dispersal ability; therefore, the biogeography of soil animals will reflect historical events in a given region. This study used more than 3000 collection records of Protura from Japan, where there is a great climatic range and a complicated history of land linkages to the Asian continent. Analysis of fauna in weakly disturbed habitats, with high species richness, enabled us to determine the invasion history of these soil organisms in Japan. This information will provide guidance for the conservation and rehabilitation of forest soil fauna.

\section{Acknowledgments}

This study was supported in part by the Global Environment Research Fund by the Ministry of the Environment, Japan (D-0909 and S-9), and a Grant-in-Aid for Science Research (A) (21241010) (the Ministry of Education, Culture, Sports, Science and Technology of Japan).

\section{References}

1. Rockstrom, J.; Steffen, W.; Noone, K.; Persson, A.; Chapin, F.S., III; Lambin, E.F.; Lenton, T.M.; Scheffer, M.; Folke, C.; Schellnhuber, H.J.; et al. A safe operating space for humanity. Nature 2009, 461, 472-475.

2. Tylianakis, J.M.; Raphael, K.D.; Jordi, B.; David, A.W. Global change and species interactions in terrestrial ecosystems. Eco. Lett. 2008, 11, 1351-1363.

3. Fierer, N.; Strickland, M.S.; Liptzin, D.; Bradford, M.A.; Cleveland, C.C. Global patterns in belowground communities. Eco. Lett. 2009, 12, 1238-1249.

4. Lilleskov, E.A.; Mattson, W.J.; Storer, A.J. Divergent biogeography of native and introduced soil macroinvertebrates in North America north of Mexico. Divers. Distrib. 2008, 14, 893-904.

5. Finlay, B.J. Gobal dispersal of free-living microbial Eukaryote species. Science 2002, 296, 1061-1063.

6. Szeptycki, A. Catalogue of the World Protura; Wydawnictwa Instytutu Systematyki I Ewolucji Zwierzat Polskiej Akademii Nauk: Krakow, Poland, 2007.

7. Chao, R.F.; Chen, C.S. The genus Eosentomon of Taiwan (Protura: Eosentomidae). Chin J. Entomol. 1996, 16, 303-321.

8. Chao, R.F.; Chen, C.S. A new species of Tuxentntulus Imadate (Protura: Acerentomidae) from Taiwan. Chin. J. Entomol. 1999, 19, 293-295.

9. Chao, R.F.; Chen, C.S. Two new species of the genus Berberentulus Tuxen (Protura: Acerentomidae) from Taiwan. Chin. J. Entomol. 1999, 19, 209-215.

10. Chao, R.F.; Lee, H.R.; Chen, C.S. Four new species of Acerentomidae (Insecta: Protura) in Taiwan. Chin. J. Entomol. 1998, 18, 235-246. 
11. Imadaté, G. Contribution to the proturan fauna of Korea. Ann. Historico-Nat. Musei Natl. Hung. 1973, 65, 151-155.

12. Imadaté, G.; Szeptycki, A. The proturans from North Korea. Bull. Natl. Sci. Mus. Tokyo Ser. A (Zoology) 1976, 2, 267-276.

13. Nakamura, O. Proturan from Taiwan. Edaphologia 1997, 59, 17-53.

14. Szeptycki, A.; Imadaté, G. The proturans from North Korea (II). Bull. Natl. Sci. Mus. Tokyo Ser. A (Zoology) 1987, 13, 165-183.

15. Yin, W.Y. Protura, Fauna Sinica, Arthropoda; Science Press: Beijing, China, 1999.

16. Imadaté, G. Protura; Keigaku Publishing Company, Ltd.: Tokyo, Japan, 1974.

17. Imadaté, G. Contributions towards a revision of the proturan fauna of Japan (I): New collecting records from Hokkaido. Bull. Coll. Liber. Arts Sci. Tokyo Med. Dent. Univ. 1979, 9, 1-17.

18. Imadaté, G. Polymorphism in Nipponentomon uenoi Imadaté et Yosii (Protura). Edaphologia 1988, 38, 17-26.

19. Imadaté, G. Contributions towards a revision of the proturan fauna of Japan(IX): Collecting data of Acerentomid and Sinentomid species in the Japanese Islands. Bull. Coll. Liber. Arts Sci. Tokyo Med. Dent. Univ. 1994, 24, 45-70.

20. Imadaté, G. Contributions towards a revision of the proturan fauna of Japan(X): Collecting data of Eosentomid species in the Japanese Islands. Bull. Coll. Liber. Arts Sci. Tokyo Med. Dent. Univ. 1995, 25, 1-37.

21. Imadaté, G.; Harada, H. Contributions towards a revision of the proturan fauna of Japan(Iii): New collecting records from Shikoku and Western Part of Honshu. Bull. Coll. Liber. Arts Sci. Tokyo Med. Dent. Univ. 1983, 13, 27-51.

22. Imadaté, G.; Harada, H. Contributions towards a revision of the proturan fauna of Japan (V): New collecting records from the Central Part of Honshu. Bull. Coll. Liber. Arts Sci. Tokyo Med. Dent. Univ. 1987, 17, 19-33.

23. Imadaté, G.; Kinjo, N. Contributions towards a revision of the proturan fauna of Japan(IV): New collecting records from the Northern Part of Honshu. Bull. Coll. Liber. Arts Sci. Tokyo Med. Dent. Univ. 1985, 15, 35-53.

24. Imadaté, G.; Nakamura, O. Contributions towards a revision of the proturan fauna of Japan (VI): New collecting records from the Eastern Part of Honshu. Bull. Coll. Liber. Arts Sci. Tokyo Med. Dent. Univ. 1989, 19, 39-76.

25. Imadaté, G.; Ohnishi, J. Contributions towards a revision of the proturan fauna of Japan (VIII): Further collecting records from Northern and Eastern Japan. Bull. Coll. Liber. Arts Sci. Tokyo Med. Dent. Univ. 1993, 23, 31-65.

26. Imadaté, G.; Tanaka, S. Contributions towards a revision of the proturan fauna of Japan(II): New collecting records from Kyushu and the Ryukyu Islands. Bull. Coll. Liber. Arts Sci. Tokyo Med. Dent. Univ. 1981, 11, 1-16.

27. Imadaté, G.; Tanaka, S. Contributions towards a revision of the proturan fauna of Japan(VII): Further collecting records from Central and Western Japan. Bull. Coll. Liber. Arts Sci. Tokyo Med. Dent. Univ. 1991, 21, 71-92.

28. Nakamura, O.; Yoshida, A. Protura. In Insect Fauna of Kanagawa; Insect Seminor of Kanagawa: Kanagawa, Japan, 2004; pp. 33-36. 
29. Nakamura, O.; Hagiwara, Y.; Tamura, H. Fauna and vertical distribution of Protura at Mt. Komogatake of the Yakeishi Mountains. J. Coll. Arts Sci. Showa Univ. 2003, 34, 1-7.

30. Nakamura, O.; Hagiwara, Y. Proturan communities under three different vegetations in adjacent area. Bull. Saitama Mus. Nat. Hist. 2006, 23, 17-22.

31. Nakamura, O. Taxonomic revision of the family Eosentomidae (Hexapoda: Protura) from Japan. Zootaxa 2010, 2701, 1-109.

32. Nakamura, O. Protura. In The 4th General Research Report of the Ibaraki Nature Museum; Ibaraki Nature Museum: Ibaraki, Japan, 2007; pp. 371-373.

33. Nakamura, O. Protura. In A Monitoring Development for the Forest Ecosystem Conservation of the Shirakami-Sanchi Wolrd Heritage Site and a Forest Management Method Development for Harmonization with Forest Utilization in Its Surrounding Area; Ministry of the Environment: Tokyo, Japan, 2004; pp. 236-238.

34. Nakamura, O. Protura. In The 3rd General Research Report of the Ibaraki Nature Museum; Ibaraki Nature Museum: Ibaraki, Japan, 2004; pp. 400-402.

35. Nakamura, O. A new species of the genus Eosentomon (Insecta: Protura: Eosentomidae) from Rishiri Island, Hokkaido, Northern Japan. Species Divers. 2004, 9, 359-366.

36. Nakamura, O. Protura and Diplura. In Research Report of the Biodiversity Area, Northern Foot of the Mount Fuji; Yamanashi Institute of Environmental Science and Ecological Research Association of Northern Foot of the Mount Fuji: Yamanashi, Japan, 2003; pp. 156-158.

37. Nakamura, O. Protura. In Soil Animals in Tochigi; Tochigi Prefecture: Tochigi, Japan, 2002; pp. 205-215.

38. Nakamura, O. Protura. In The 2nd General Research Report of the Ibaraki Nature Museum; Ibaraki Nature Museum: Ibaraki, Japan, 2001; pp. 368-371.

39. Nakamura, O. A new species of the genus Filientomon from Central Japan (Protura: Acerentomidae). Edaphologia 2001, 31, 33-37.

40. Nakamura, O. Corrections to and notes on Protura and Diplura in "Soil Arthropod Biota of Chiba City” (Ishii 1996, 1997). Bull. Saitama Mus. Nat. Hist 2000, 18, 1-6.

41. Nakamura, O. Proturans from the garden of the Imperial Palace, Tokyo. Mem. Natl. Sci. Mus. Tokyo 2000, 36, 497-504.

42. Nakamura, O. The records of Protentomidae. Edaphologia 1999, 62, 97.

43. Nakamura, O. Soil animals of Kami-Izumi village. In Kami-Izumi Mura Shi Shizen-Hen Mokuroku; Kami-Izumi Mura: Saitama, Japan, 1999; pp. 139-145.

44. Nakamura, O. Occurrence of Paracerella shiratki Imadaté (Protura, Acerentomidae) in Honshu. Edaphologia 1999, 63, 87.

45. Nakamura, O. Protura from the Tajimagahara Wild Primrose Field, Urawa, Saitama. Bull. Saitama Mus. Nat. Hist 1999, 17, 1-3.

46. Nakamura, O. The proturans from and around the Ozegahara moor. In Scientific Research of the Oze Area in central Japan; Oze Scientific Research Group: Tochigi, Japan, 1998; pp. 328-330.

47. Nakamura, O. Protura. In The 1st General Research Report of the Ibaraki Nature Museum; Ibaraki Nature Museum: Ibaraki, Japan, 1998; pp. 328-330.

48. Nakamura, O. A new species of the genus Pseudanisentomon (Protura, Eosentomidae) from Central Japan. Edaphologia 1996, 57, 7-12. 
49. Nakamura, O. A new species and a new record of the genus Baculentulus (Protura, Acerentomidae) from Japan. Jpn. J. Entomol. 1995, 63, 333-345.

50. Nakamura, O. A new species of the genus Gracilentulus (Protura) from Japan. Edaphologia 1995, $54,1-8$.

51. Nakamura, O. Proturans collected from roof garden of the building of the Saitama Museum of Natural History. Bull. Saitama Mus. Nat. Hist. 1994, 12, 61-63.

52. Bu, Y.; Yin, W.Y. A new species of proturan from Northeast China (Protura, Acerentomidae). Acta Zootaxonomica Sin. 2007, 32, 56-60.

53. Bu, Y.; Yin, W.Y. Occurrence of Nosekiella Rusek 1974 and Nienna Szeptycki 1988 (Protura: Nipponentomidae: Verrucoentominae) in China. Ann. Soc. Entomol. Fr. 2008, 44, 201-207.

54. Maehara, T.; Hagiwara, Y.; Ishii, K.; Ito, R.; Kurozumi, T.; Sakayori, H.; Suganami, Y.; Tamura, H.; Chinone, S.; Nakamura, O.; et al. Soil animals from Rishiri Island, Northern Hokkaido. Rishiri Stud. 2003, 22, 55-72.

55. Suma, Y.; Hirauchi, Y.; Ishii, K.; Ishikawa, K.; Shiba, M.; Nomura, S.; Sato, H.; Asama, S.; Ishizuka, K.; Nakamura, O.; et al. Fauna of soil animals of Minami-Rokuroshi Highland. Bull. Toyama Sci. Mus. 2002, 25, 69-87.

56. Takai, Y. Invertebrates fauna in the Miya Village. In Miya-Son-Shi Shizenshi-Shiryo; Miya Village: Gifu, Japan, 2004; pp. 51-203.

57. Wu, D.H.; Yin, W.Y. New records of the genera Acerentulus and Brasilidia (Protura: Acerentomidae) from China, with description of two new species. Zootaxa 2007, 1561, 53-61.

58. Wu, D.H.; Yin, W.Y. The protura from Changbai Mountain, Northeastern China I: Genera Chosonentulus Imadaté \& Szeptycki and Filientomon Rusek. Ann. Soc. Entomol. Fr. 2008, 44, 379-384.

59. Wu, D.H.; Yin, W.Y. Two new species of Protura (Protentomidae and Hesperentomidae) from Northeastern China. Orient. Insects 2008, 42, 237-246.

60. The Free Address Geocoding Service of CSV Formatted Files; The University of Tokyo Website. Available online: http://newspat.csis.u-tokyo.ac.jp/geocode/modules/addmatch/index.php? content_id=1/(assessed on 24 August 2012).

61. Hill, M.O. TWINSPAN: A Fortran Program for Arranging Multivariate Data in an Ordered Two-way Table by Classification of the Individuals and Attributes; Ecology and Systematics, Cornell University: Ithaca, NY, USA, 1979.

62. McCune, B.; Mefford, M. PC-ORD for Windows: Multivariate Analysis of Ecological Data. Version 4; MjM Software Desing: Gleneden Beach, OR, USA, 1999.

63. R Development Core Team. $R$ : A Language and Environment for Statistical Computing; R Foundation for Statistical Computing: Vienna, Austria, 2011.

64. Dufrêne, M.; Legendre, P. Secies assemblages and indicator specires: The need for a flexibile asymmetrial approach. Ecolog. Monogr. 1997, 67, 345-366.

65. Borcard, D.; Gillet, F.; Legendre, P. Numerical Ecology with R; Springer Science + Business Media: New York, NY, USA, 2011.

66. Mesh Climate Data of Japan; Japan Meteological Agency Website. Available online: http://data.sokki.jmbsc.or.jp/cdrom/mesh_climatic_data/documents/index_e.htm/ (assessed on 24 August 2012). 
67. Colwell, R.K.; Coddington, J.A. Estimating terrestrial biodiversity through extraporation. Philos. Trans. R. Soceity B 1994, 345, 101-118.

68. Imadate, G.; Ohnishi, J. Contributions towards a revision of the proturan fauna of Japan (VIII): Further collecting records from northern and eastern Japan. Bull. Coll. Liber. Arts Sci. Tokyo Med. Dent. Univ. 1993, 23, 31-65.

69. Saito, S.; Yokoyama, K.; Tsutsumi, Y.; Tanimura, Y. Formation of Japanese Islands. In Natural History of the Japanese Islands; Tohkai University Press: Kanagawa, Japan, 2006; pp. 23-40.

70. Ohshima, K. The history of straits around the Japanese Islands in the Late-Quaternary. Quat. Res 1990, 29, 193-208.

71. Ohshima, K. History of straits formation. Determine factor as animal distributions. Geol. News 1978, 289, 14-24.

\section{Appendix}

Table A1. Species list of Protura recorded in the data set.

\begin{tabular}{|c|c|c|}
\hline Suborder & Family & Species \\
\hline & Protentomidae & $\begin{array}{l}\text { Fujientomon primum Imadaté, } 1964 \\
\text { Huhentomon plicatunguis haradai Imadaté, } 1989 \\
\text { Hesperentomon kuratai Imadaté, } 1989 \\
\text { Hinomotentomon nipponicum (Imadaté, 1964) } \\
\text { Neocondeellum japonicum Nakamura, } 1990 \\
\text { N. matobai (Imadaté, 1974) } \\
\text { N. minusculum Nakamura, } 1990\end{array}$ \\
\hline Acerentomoidea & 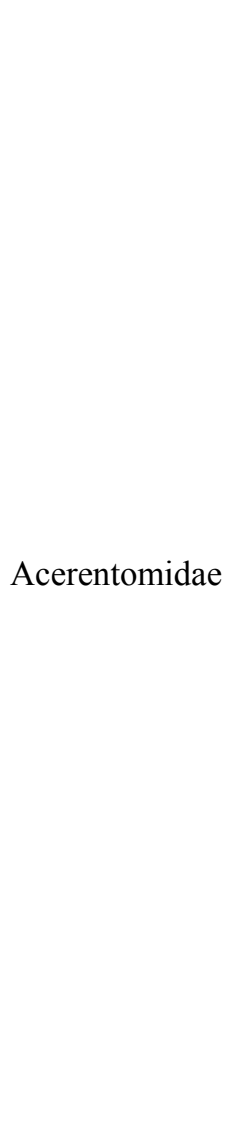 & $\begin{array}{l}\text { Acerentulus keikoae capillatus Imadaté, } 1988 \\
\text { A. k. keikoae Imadaté, } 1988 \\
\text { A. kisonis Imadaté, } 1961 \\
\text { A. omoi Imadaté, } 1988 \\
\text { Tuxenentulus ohbai Imadaté, } 1974 \\
\text { Wenyingia kurosawai (Imadaté, 1986) } \\
\text { Sugaentulus masumii Imadaté, 1978 } \\
\text { Yamatentomon fujisanum Imadaté, 1964 } \\
\text { Y. kunnepchupi Imadaté, 1964 } \\
\text { Y. yamato (Imadaté et Yosii, 1956) } \\
\text { Filientomon gentaroanum Nakamura, 2001 } \\
\text { F. kurosai (Imadaté, 1974) } \\
\text { F. lubricum (Imadaté, 1956) } \\
\text { F. takanawanum (Imadaté, 1956) } \\
\text { Kenyentulus japonicus (Imadaté, 1961) } \\
\text { K. monticola Nakamura, 1990 } \\
\text { K. sakimori (Imadaté, 1977) } \\
\text { Gracilentulus aokii Imadaté, 1982 } \\
\text { G. chichibuensis Nakamura, 1995 } \\
\text { Baculentulus densus (Imadaté, 1960) } \\
\text { B. loxoglenus Yin, 1980 } \\
\text { B. morikawai (Imadaté et Yosii, 1956) }\end{array}$ \\
\hline
\end{tabular}


Table A1. Cont.

\begin{tabular}{|c|c|c|}
\hline Suborder & Family & Species \\
\hline Acerentomoidea & Acerentomidae & $\begin{array}{l}\text { B. nipponicus Nakamura, } 1985 \\
\text { B. nitidus (Imadaté et Yosii, 1959) } \\
\text { B. sakayorii Nakamura, 1995 } \\
\text { B. tosanus (Imadaté et Yosii, 1959) } \\
\text { Neobaculentulus izumi (Imadaté, 1965) } \\
\text { Silvestridia hutan Imadaté, 1965 } \\
\text { Verrucoentomon kawakatsui (Imadaté, 1964) } \\
\text { Nosekiella urasi Imadaté, 1981 } \\
\text { Paracerella shiratki (Imadaté, 1964) } \\
\text { Imadateiella shideiana eos (Imadaté, 1974) } \\
\text { I. s. shideiana (Imadaté, 1964) } \\
\text { I. shiria (Imadaté, 1964) } \\
\text { I. yosiiana (Imadaté, 1961) } \\
\text { I. shiria (Imadaté, 1964) } \\
\text { I. yosiiana (Imadaté, 1961) } \\
\text { Nipponentomon kamui Imadaté, } 1965 \\
\text { N. nippon (Yoshii, 1938) } \\
\text { N. uenoi uenoi Imadaté et Yosii, } 1959 \text { [f. A] } \\
\text { N. uenoi paucisetosum Imadaté, } 1965 \text { [f. B] } \\
\text { N. uenoi paucisetosum Imadaté, } 1965 \text { [f. C] } \\
\text { N. uenoi paucisetosum Imadaté, } 1965 \text { [f. D] } \\
\text { N. uenoi paucisetosum Imadaté, } 1965 \text { [f. E] } \\
\text { N. uenoi paucisetosum Imadaté, } 1965 \text { [f. F] }\end{array}$ \\
\hline Sinentomoidea & Sinentomidae & Sinentomon yoroi Imadaté, 1977 \\
\hline Eosentomoidea & Eosentomidae & $\begin{array}{l}\text { Eosentomon asahi Imadaté, } 1961 \\
\text { E. asakawaense Imadaté, } 1961 \\
\text { E. dounanense Imadaté, } 1994 \\
\text { E. juni Imadaté, } 1994 \\
\text { E. kimum Imadaté, } 1964 \\
\text { E. konsenense Imadaté, } 1994 \\
\text { E. kumei Imadaté et Yosii, } 1959 \\
\text { E. nupri Nakamura, } 1983 \\
\text { E. pacificum Imadaté et Yosii, } 1959 \\
\text { E. rishir } \text { Nakamura, } 2004 \\
\text { E. sakura Imadaté et Yosii, } 1959 \\
\text { E. toi Imadaté, } 1964 \\
\text { E. tokiokai Imadaté, } 1964 \\
\text { E. tokui Imadaté, } 1974 \\
\text { E. topochi Imadaté, } 1964 \\
\text { E. yezoense Nakamura, } 1983 \\
\text { Paranisentomon tuxeni (Imadaté et Yosii, 1959) } \\
\text { Pseudanisentomon babai (Imadaté, 1964) } \\
\text { P. ishiii Nakamura,1996 }\end{array}$ \\
\hline
\end{tabular}


Table A2. IndVal species selected from the three assembly groups of Protura.

\begin{tabular}{|c|c|c|c|c|}
\hline Species & Group & IndVal & $P$ value & Frequency \\
\hline Eosentomon asakawaense & 1 & 0.67 & 0.001 & 48 \\
\hline Eosentomon asahi & 1 & 0.63 & 0.001 & 56 \\
\hline Nipponentomon uenoi paucisetosum [f. B] & 1 & 0.37 & 0.001 & 48 \\
\hline Acerentulus k. keikoae & 1 & 0.32 & 0.001 & 23 \\
\hline Baculentulus sakayorii & 1 & 0.17 & 0.001 & 8 \\
\hline Tuxenentulus ohbai & 1 & 0.13 & 0.049 & 19 \\
\hline Imadateiella shideiana eos & 1 & 0.09 & 0.049 & 8 \\
\hline Eosentomon sakura & 2 & 0.37 & 0.004 & 102 \\
\hline Filientomon takanawanum & 2 & 0.33 & 0.001 & 46 \\
\hline Paranisentomon tuxeni & 2 & 0.32 & 0.002 & 69 \\
\hline Baculentulus tosanus & 2 & 0.29 & 0.032 & 83 \\
\hline Eosentomon asakawaense & 1 & 0.67 & 0.001 & 48 \\
\hline Eosentomon asahi & 1 & 0.63 & 0.001 & 56 \\
\hline Nipponentomon uenoi paucisetosum [f. B] & 1 & 0.37 & 0.001 & 48 \\
\hline Acerentulus k. keikoae & 1 & 0.32 & 0.001 & 23 \\
\hline Baculentulus sakayorii & 1 & 0.17 & 0.001 & 8 \\
\hline Tuxenentulus ohbai & 1 & 0.13 & 0.049 & 19 \\
\hline Imadateiella shideiana eos & 1 & 0.09 & 0.049 & 8 \\
\hline Eosentomon sakura & 2 & 0.37 & 0.004 & 102 \\
\hline Filientomon takanawanum & 2 & 0.33 & 0.001 & 46 \\
\hline Paranisentomon tuxeni & 2 & 0.32 & 0.002 & 69 \\
\hline Baculentulus tosanus & 2 & 0.29 & 0.032 & 83 \\
\hline Nipponentomon uenoi paucisetosum [f. C] & 2 & 0.20 & 0.001 & 7 \\
\hline Acerentulus omoi & 2 & 0.14 & 0.003 & 5 \\
\hline Acerentulus kisonis & 2 & 0.13 & 0.042 & 17 \\
\hline Yamatentomon yamato & 2 & 0.09 & 0.048 & 10 \\
\hline Nipponentomon uenoi paucisetosum [f. D] & 2 & 0.09 & 0.019 & 3 \\
\hline Kenyentulus japonicus & 3 & 0.57 & 0.001 & 77 \\
\hline Eosentomon tokiokai & 3 & 0.47 & 0.001 & 37 \\
\hline Neocondeellum japonicum & 3 & 0.19 & 0.001 & 12 \\
\hline Nipponentomon uenoi uenoi $[\mathrm{f} . \mathrm{A}]$ & 3 & 0.16 & 0.001 & 10 \\
\hline Filientomon lubricum & 3 & 0.15 & 0.003 & 9 \\
\hline Baculentulus nitidus & 3 & 0.11 & 0.015 & 11 \\
\hline Neobaculentulus izumi & 3 & 0.11 & 0.032 & 11 \\
\hline
\end{tabular}

(C) 2012 by the authors; licensee MDPI, Basel, Switzerland. This article is an open access article distributed under the terms and conditions of the Creative Commons Attribution license (http://creativecommons.org/licenses/by/3.0/). 